1. Western blotting Raw Data

(Figure 5C)

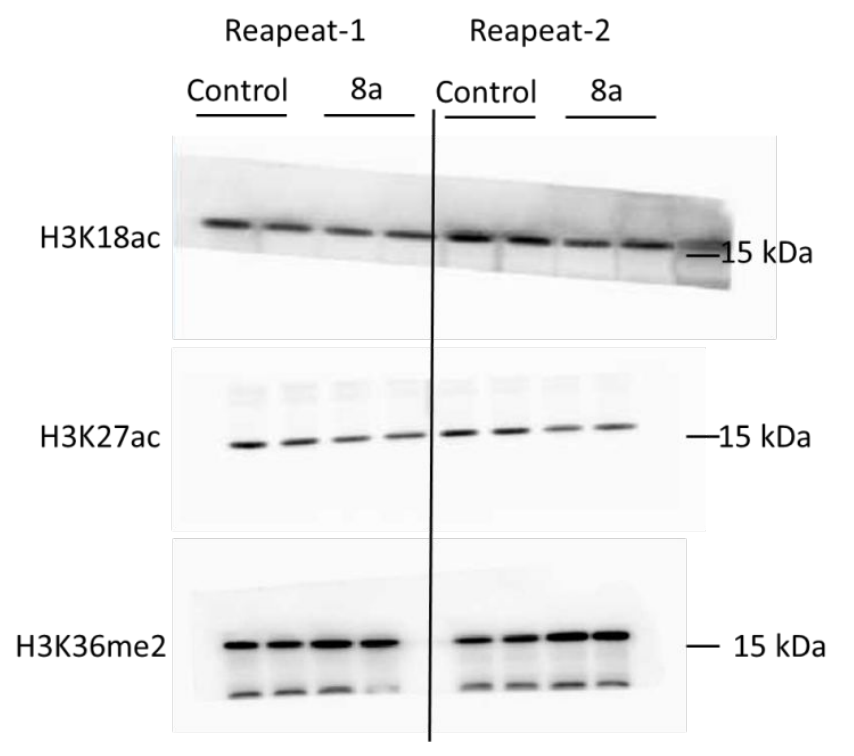

Control 8a

H3

$-15 \mathrm{kDa}$

(Figure 5D)

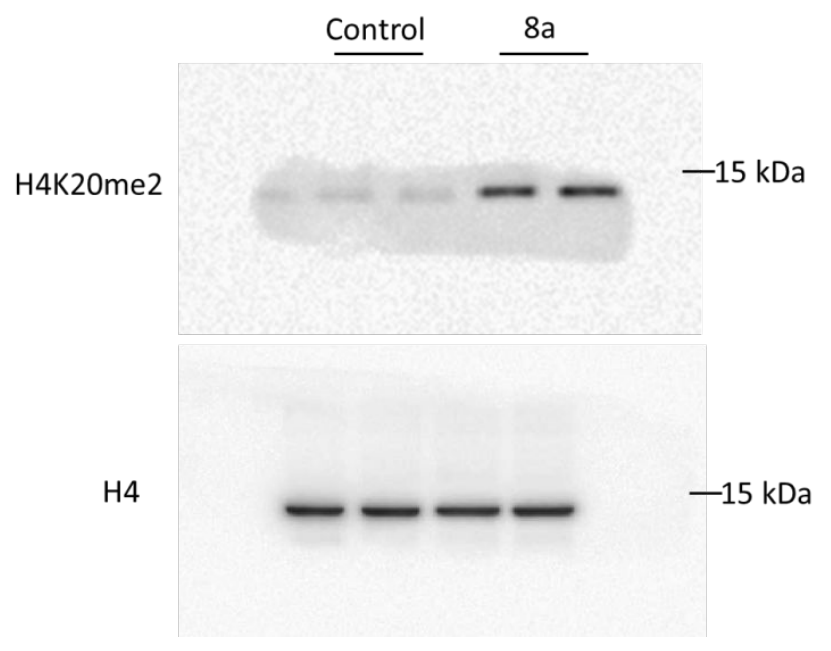


2. Immunoprecipitation Raw Data

\section{(Figure 6A)}

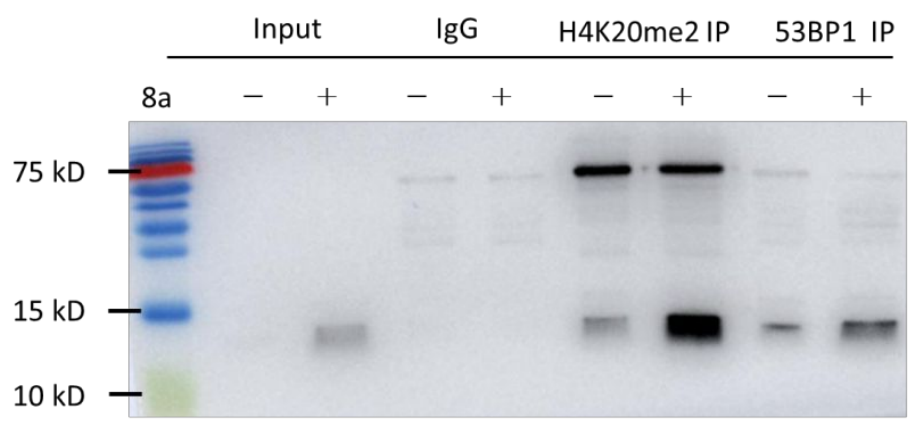

\section{(Figure 6B)}

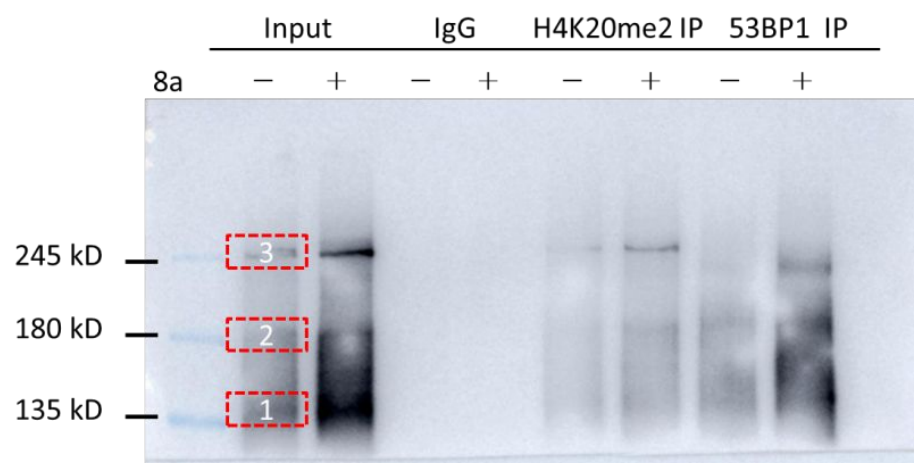

In our western blotting results, we find one specific 53BP1 band at $245 \mathrm{kDa}$, and two non-specific bands at 180 and $135 \mathrm{kDa}$. So we cut the gel located at these specific molecular weight (band 1-3 in above dotted box), digest the gels followed by LC-MS analysis. The MS results show that the specific $245 \mathrm{kDa}$ band is predominant 53BP1 band, so we select the band 3 as specific 53BP1 band in Figure 6B.

The detailed information of above 3 bands is listed as follows.

\begin{tabular}{|c|c|c|c|c|c|c|c|c|c|c|c|c|c|}
\hline band & Protein & $\begin{array}{l}\text { Sum PEP } \\
\text { Score }\end{array}$ & Coverage & $\begin{array}{l}\# \\
\text { Peptides }\end{array}$ & $\begin{array}{l}\# \\
\text { PSMs }\end{array}$ & $\begin{array}{l}\text { \# Unique } \\
\text { Peptides }\end{array}$ & $\begin{array}{l}\# \\
\text { AAs }\end{array}$ & $\begin{array}{l}\text { MW } \\
\text { [kDal }\end{array}$ & $\begin{array}{l}\text { calc. } \\
\text { pl }\end{array}$ & Area & emPAl & $\begin{array}{l}\text { Score } \\
\text { Mascot }\end{array}$ & $\begin{array}{l}\text { \# Peptides } \\
\text { Mascot }\end{array}$ \\
\hline 1 & 53BP1 & 68.399 & 13.35357 & 19 & 48 & 19 & 1977 & 214 & 4.7 & $8.95 E+07$ & 0.73 & 809 & 19 \\
\hline 2 & 53BP1 & 172.942 & 24.27921 & 31 & 82 & 31 & 1977 & 214 & 4.7 & $3.45 E+08$ & 2.728 & 1856 & 31 \\
\hline 3 & 53BP1 & 213.875 & 25.44259 & 39 & 98 & 39 & 1977 & 214 & 4.7 & $6.99 \mathrm{E}+08$ & 4.067 & 2292 & 39 \\
\hline
\end{tabular}

